\title{
PERANAN ORANGTUA DALAM MENDUKUNG REGENERASI PETANI PADI (ORYZA SATIVA L) DI DESA SRIKATON KECAMATAN BUAY MADANG TIMUR
}

\author{
Oleh \\ Myxa Cezar Ranzez ${ }^{1)}$, Oeng Anwarudin ${ }^{2)}$ \& Maspur Makhmudi ${ }^{3)}$ \\ 1,3 Jurusan Pertanian Politeknik Pembangunan Pertanian Bogor \\ 2Jurusan Pertanian Politeknik Pembangunan Pertanian Manokwari \\ Email: ${ }^{1}$ abang.royyy9@ gmail.com, 2 oenganwarudin@gmail.com \& \\ ${ }^{3}$ maspurmakhmudi5@gmail.com
}

\begin{abstract}
One of agent who has a role to play in the regeneration of farmers in one area and can be performed early on is the parent. Parents, therefore, have an important role to play in supporting the regeneration of farmers. Research aims to analyze descriptive and unifying roles that parents play in supporting the regeneration of rice farmers (oryza sativa 1) and analyze the effects of the roles of parents of individual characteristics, age, occupational experience, a broader landscape and external factors that include lifestyle, education and government support for the development of rice farmers (oryza sativa 1). Research has been conducted in east buay madang, ogan combo east, south Sumatra. The research population is made up of farm parents who make farmers. Samples are selected as many as 70 people using cluser random sampling techniques. The conversion of this study consists of individual characteristics, external factors and the role of parents. Data analysis techniques use desktop statistical analysis mean, percentage and inductive /inferens) that is multiple regression. The results of weavers have been determined to assume that both the external factors and the role of the parents fall into high categories. The role of parents is influenced by external factors. Thus, to preserve the continued role of parents in supporting the regeneration of rice farmers (oryza sativa 1) could be done by increasing the external factor of lifestyle, parental role and government support.
\end{abstract}

Keywords: Farmer's Rice, Role Of The Parent \& Regeneration Of The Farmer

\section{PENDAHULUAN}

Salah satu faktor keberhasilan dalam membangun dan mengembangkan pertanian yang maju, mandiri, dan modern adalah tersedianya sumber daya yang berkualitas dan berkelanjutan. Untuk itu, dibutuhkan tiga faktor yaitu Sumber Daya Alam, Sumber Daya Manusia dan teknologi tepat guna (Ritonga et al. 2015). Namun dalam pembangunan pertanian masih mengalami permasalahan yang cukup serius. Badan Pusat Statistik (BPS) mencatat bahwa dalam kurun 10 tahun, 20032013, jumlah rumah tangga petani berkurang sebanyak 5 juta (BPS, 2013). Hal ini yang dikhawatirkan terhadap generasi petani di Indonesia. Apabila tidak diperhatikan, akan terjadi penurunan jumlah petani Indonesia yang berkelanjutan.
Sebenarnya pihak yang dapat berinteraksi secara langsung dan dapat dilakukan regenerasi sejak dini adalah orang tua. Orang tua di dalam suatu keluarga memiliki peran penting dan pengaruh besar terhadap generasi mereka. Peranan orang tua menurut Joose dan Grubbstrom, (2017) menyatakan bahwa peranan orangtua mencakup sosialisasi, respek, dan warisan. Harapannya para orang tua memberikan respek, sosialisasi, warisan bidang pertanian yang baik terhadap generasi mereka. Dengan demikian regenerasi petani dapat tercipta sejak dini dari dalam lingkungan keluarga. Penelitian ini bertujuan untuk menganalisis data secara desktiptif peranan orang tua dalam mendukung regenerasi petani padi (Oryza sativa L.). Tujuan selanjutnya menganalisis pengaruh peranan orang tua 
dalam mendukung regenerasi petani padi (Oryza sativa L.).

Adapun rumusan masalah dalam pengkajian peranan orangtua dalam mendukung regenerasai petani padi (Oryza sativa L.) di Desa Srikaton, Kecamatan Buay Madang Timur adalah:

1. Bagaimana peranan orangtua dalam mendukung regenerasai petani padi di Desa Srikaton, Kecamatan Buay Madang Timur?

2. Faktor-faktor apa saja yang berpengaruh terhadap peranan orangtua dalam mendukung regenerasi petani padi di Desa Srikaton, Kecamatan Buay Madang Timur?

3. Bagaimana strategi untuk penguatan peranan orangtua dalam mendukung regenerasi petani padi (Oryza sativa L.) di Desa Srikaton, Kecamatan Buay Madang Timur?

Tujuan dari pengkajian peranan orangtua dalam mendukung regenerasai petani padi (Oryza sativa L.) di Desa Srikaton, Kecamatan Buay Madang Timut adalah:

1. Mendeskripsikan peranan orangtua dalam mendukung regenerasi petani padi di Desa Srikaton, Kecamatan Buay Madang Timur.

2. Menganalisis faktor-faktor yang berpengaruh terhadap peranan orangtua dalam mendukung regenerasi petani padi di Desa Srikaton, Kecamatan Buay Madang Timur.

3. Menyusun strategi penguatan peranan orangtua dalam mendukung regenerasi petani padi di Desa Srikaton, Kecamatan Buay Madang Timur.

Manfaat yang dapat diambil dalam pengkajian peranan orangtua dalam mendukung regenerasi petani padi (Oryza sativa L.) di Kecamatan Buay Madang Timur, Kabupaten Ogan Komering Ulu Timur adalah:

1. Bagi Petani

a. Memperoleh ilmu pengetahuan baru tentang bagaimana pentingnya peranan orangtua dalam mendukung regenerasi pertanian.

b. Menjalin ikatan tali silaturahmi antar anggota petani, penyuluh dan mahasiswa.
2. Bagi Instansi

a. Sebagai bahan referensi bagi mahasiswa.

b. Menambah relasi antar kampus dan lembagatani setempat.

3. Bagi Penulis

a. Dapat menambah pengetahuan dan pengalaman tentang peranan orangtua dalam mendukung regenerasi petani padi (Oryza sativa L.) di Kecamatan Buay Madang Timur Kabupaten Ogan Komering Ulu Timur.

b. Dapat mengaplikasikan ilmu yang diperoleh dari bangku perkuliahan.

\section{LANDASAN TEORI}

\section{Penyuluhan Pertanian}

Penyuluhan berdasarkan UndangUndang Nomor 16 Tahun 2006 (SP3K) adalah penyuluhan pertanian, perikanan, kehutanan yang selanjutnya disebut penyuluhan adalah proses pembelajaran bagi pelaku utama serta pelaku usaha agar mereka mau dan mampu menolong dan mengorganisasikan dirinya dalam mengakses informasi pasar, teknologi, permodalan, dan sumber daya lainnya, sebagai upaya untuk meningkatkan produktivitas, efisiensi usaha, pendapatan dan kesejahteraannya, serta meningkatkan kesadaran dalam pelestarian fungsi lingkungan hidup.

\section{Pertanian Berkelanjutan}

FAO (1989), menyatakan bahwa pertanian berkalanjutan (sustainable agriculture) merupakan pengelolaan konservasi Sumber Daya Alam dan berorientasi pada perubahan teknologi dan kelembagaan yang dilakukan sedemikian rupa untuk menjamin pemenuhan dan pemuasan kebutuhan manusia secara berkelanjutan bagi generasi sekarang dan mendatang.

\section{Generasi Muda}

Nazaruddin \& Anwarudin, (2017), menyatakan bahwa generasi muda adalah generasi yang belum banyak memiliki pengalaman, walaupun dari sekian banyak generasi muda adalah anak petani, belum tentu 
dalam keseharian mereka ikut terlibat dalam bidang pertanian.

Regenerasi Petani

Zagata dan Sutherland (2015), menafsirkan regenerasi petani sebagai proses penyerahan secara konsisten aktor pengganti yang berkaitan dengan bisnis pertanian. Sottomayor dan al. (2011), menyatakan bahwa regenerasi diperlukan untuk menemukan pengganti dari para petani yang sudah memasuki masa-masa tidak produktif atau lanjut usia. Lobley dan Baker (2012), menyatakan bahwa regenerasi petani sebagai proses yang melibatkan perencanaan aktif untuk mentransfer aset pertanian.

\section{Petani}

Petani berdasarkan Undang-Undang Nomor 16 Tahun 2006 (SP3K) adalah Petani adalah perorangan warga negara Indonesia beserta keluarganya atau korporasi yang mengelola usaha di bidang pertanian, wanatani, minatani, agropasture, penangkaran satwa dan tumbuhan, di dalam dan di sekitar hutan, yang meliputi usaha hulu, usaha tani, agroindustri, pemasaran, dan jasa penunjang.

\section{Peranan Orangtua}

Orangtua memiliki peran dalam mengubah generasi muda menjadi petani dan menjadi pengusaha pertanian. Peranan orang tua dalam kajian ini mencakup respek, sosialisasi, dan warisan (Joose dan Grubbstrom, 2017).

\section{Karakteristik Individu}

Mardikanto (2009), menyatakan karakteristik individu adalah sifat-sifat yang melekat pada diri seseorang dan berhubungan dengan aspek kehidupan antara lain umur, jenis kelamin, posisi jabatan, status sosial, dan agama. Pada pengkajian ini yang akan diukur adalah umur, pendidikan, lama berusaha tani, dan luas lahan garapan.

\section{Faktor Eksternal}

Faktor eksternal adalah faktor penyebab perilaku petani yang berasal dari lingkungan atau situasi sekitarnya (Nurmalina et al. 2018). Faktor yang akan di kaji dalam pengkajian ini adalah gaya hidup, peranan penyuluh dan dukugan pemerintah.

\section{Kerangka Berpikir}

Berdasarkan studi pustaka pada landasan teori, ditemukan bahwa peran orangtua terhadap generasi petani padi dipengaruhi oleh karakteristik individu dan faktor eksternal. Peran orangtua memiliki tiga indikator yaitu respek, sosialisasi, dan pewarisan. Karakteristik individu memiliki empat indikator yaitu umur, pendidikan, pengalaman bertani, dan luas lahan. Kemudian untuk faktor eksternal memiliki tiga indokator yaitu gaya hidup, peran penyuluh, dan dukungan pemerintah.

Gambar 1. Kerangka berpikir peranan orangtua dalam mendukung regenerasi petani padi (Oryza sativa L.) Kecamatan Buay Madang Timur

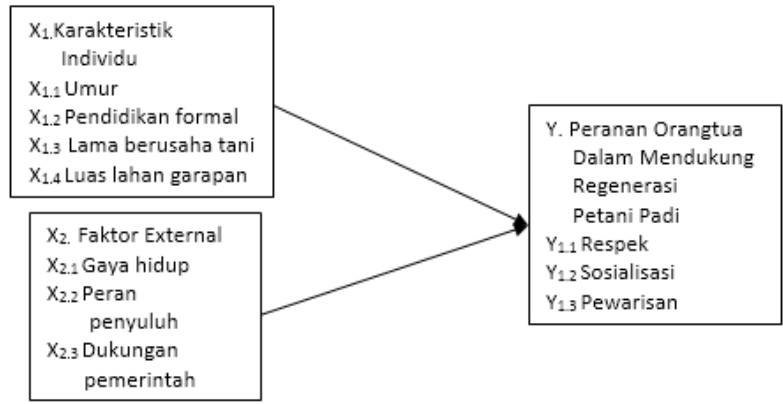

\section{METODE PENELITIAN}

Waktu dan Tempat

$$
\text { Kegiatan Tugas Akhir }
$$

dilaksanakan selama lima bulan (Februari-Juli 2020). Dengan lokasi berada di Desa Srikaton, Kecamatan Buay Madang Timur, Kabupaten Ogan Komering Ulu Timur, Provinsi Sumatera Selatan.

\section{Populasi dan Sampel}

Populasi dalam pelaksanaan pengkajian adalah pelaku utama dan pelaku usaha tani yang berada di Desa Srikaton, Kecamatan Buay Madang Timur sebanyak 204 orang. Populasi penelitian merupakan anggota kelompoktani yang secara rinci ditampilkan padaTabel 1.

Tabel 1. Jumlah Anggota Kelompok Tani di Desa Srikaton

\begin{tabular}{|c|c|c|c|}
\hline No. & Desa & Nama Poktan & $\begin{array}{c}\text { Jumlah } \\
\text { Anggota } \\
\text { (orang) }\end{array}$ \\
\hline 1. & Srikaton & Rahayu Sentosa & 31 \\
\hline 2. & & Tirto Rahayu & 35 \\
\hline
\end{tabular}




\begin{tabular}{|c|c|c|c|}
\hline No. & Desa & Nama Poktan & $\begin{array}{c}\text { Jumlah } \\
\text { Anggota } \\
\text { (orang) }\end{array}$ \\
\hline 3. & & Rukun Tani & 45 \\
\hline 4. & & Karya Maju I & 59 \\
\hline 5. & & Sumber Tani & 34 \\
\hline & & Jumlah & $\mathbf{2 0 4}$ \\
\hline
\end{tabular}

Sampel penelitian adalah perwakilan yang representatif dari pelaku utama (petani) dan pelaku usaha (pengusaha tani) yang tergabung dalam kelompok tani yang ada di Kecamatan Buay Madang Timur. Penentuan jumlah sampel dari populasi menggunakan rumus Slovin, sebagai berikut:

Keterangan:

$$
\mathbf{n}=\frac{\mathbf{N}}{1+\mathrm{Ne}^{2}}
$$

$\mathrm{n}=$ Jumlah Sampel

$\mathrm{N}=$ Jumlah anggota kelompok tani yang terpilih

$\mathrm{e}=$ derajat error $(10 \%)$

Sehingga ukuran sampel pengkajian ini yaitu sebagai berikut.

$$
\begin{aligned}
\mathbf{n}=\frac{204}{1+\left(204 \times 0,1^{2}\right)} \\
n=\frac{204}{3,04} \\
n=67,10 \rightarrow 68
\end{aligned}
$$

Berdasarkan perhitungan di atas diketahui jumlah sampel yang akan diambil dalam pelaksanaan Tugas Akhir ini adalah 68 responden. Metode pemilihan sampel dalam pengkajian ini adalah metode random sampling. Responden dipilih secara acak yang diyakini dapat mewakili populasi sebenarnya. Untuk memudahkan jumlah sampel yang diambil dalam enam kelompoktani tersebut, perlu dilakukan proporsional sampel menggunakan rumus Rubin and Luck, yaitu:

Keterangan:

$$
\mathbf{N i}=\frac{\mathbf{N k}}{\mathbf{N}}(\mathbf{n})
$$

$\mathrm{Ni}=$ Jumlah petani sampel dari masing-masing kelompoktani

$\mathrm{Nk}=$ Jumlah petani dari masingmasing kelompoktani

$\mathrm{N}=$ Jumlah total petani dari semua kelompoktani (populasi) $\mathrm{n} \quad=$ Jumlah petani yang ingin diambil dalam penelitian

Berdasarkan teori tersebut diketahui

\begin{tabular}{|c|c|c|c|c|}
\hline No & $\begin{array}{l}\text { Nama } \\
\text { Poktan }\end{array}$ & $\begin{array}{c}\text { Jumlah } \\
\text { Anggota } \\
\text { (Orang) }\end{array}$ & Perhitungan & $\begin{array}{c}\text { Jumlah } \\
\text { Responden } \\
\text { Per Poktan }\end{array}$ \\
\hline 1. & $\begin{array}{l}\text { Rahayu } \\
\text { Sentosa }\end{array}$ & 31 & $(31 / 204) \times 68$ & 11 \\
\hline 2. & $\begin{array}{c}\text { Tirto } \\
\text { Rahayu }\end{array}$ & 35 & $(35 / 204) \times 68$ & 12 \\
\hline 3. & Rukun Tani & 45 & $(45 / 204) \times 68$ & 15 \\
\hline 4. & $\begin{array}{c}\text { Karya Maju } \\
\text { I }\end{array}$ & 59 & $(59 / 204) \times 68$ & 20 \\
\hline 5. & $\begin{array}{c}\text { Sumber } \\
\text { Tani }\end{array}$ & 34 & $(34 / 204) \times 68$ & 12 \\
\hline & Jumlah & 204 & & 70 \\
\hline
\end{tabular}
cara penghitungan dan jumlah sampel pada setiap kelompoktani seperti pada Tabel 2.

Tabel 2. Proposional Sampel dalam Setiap Kelompoktani

Berdasarkan Tabel 2, sampel yang diambil di Desa Srikaton sebanyak 70 orang dari kelompoktani Rahayu Sentosa 11 orang, poktan Tirto Rahayu 12 orang, poktan Rukun Tani 15 orang, poktan Karya Maju I 20 orang dan Desa Bantarwaru sebanyak 20 orang dari dua kelompoktani yaitu kelompoktani Cijambe 10 orang dan kelompoktani Sumber Tani 12 orang. Pada kegiatan Tugas Akhir (TA) penyuluhan pertanian yang akan dilaksanakan di Desa Srikaton, Kecamatan Buay Madang Timur, Kabupaten Ogan Komering Ulu Timur berjumlah 70 orang sampel responden yang diharapkan data yang diperoleh dapat mewakili setiap anggota kelompoktani yang ada di desa tersebut.

\section{Instrumen Pengkajian Kisi-kisi Instrumen}

Instrumen pengkajian terdiri dari variabel-variabel. Instrumen yang digunakan dalam kajian ini terdiri dari dua variabel, yaitu variabel bebas $(\mathrm{X})$ dan variabel terikat $(\mathrm{Y})$.

1. Variabel bebas $(\mathrm{X})$ terdiri dari:

a. Karakteristik Individu $\left(\mathrm{X}_{1}\right)$ merupakan cirri-ciri yang melekat pada petani yang meliputi umur, pendidikan formal, 
pengalaman berusahatani, dan luas lahan yang digarapan.

b. Faktor Eksternal $\left(\mathrm{X}_{2}\right)$ adalah faktor yang diduga memiliki pengaruh terhadap peran orangtua terhadap generasi petani padi. Faktor eksternal meliputi gaya hidup, peran penyuluh, dan dukungan pemerintah.

2. Variabel terikat (Y) adalah peran orangtua yang dicirikan dengan respek, sosialisasi dan pewarisan.

Instrumen yang digunakan berupa kuesioner terbuka pada bagian variabel $X_{1}$ dan keusioner tertutup pada bagian variabel $\mathrm{X}_{2}$ dan variabel Y. Setiap butir pertanyaan dan/atau pernyataan disediakan beberapa alternatif jawaban yang dapat dipilih oleh responden sesuai dengan pengetahuan, persepsi, perasaan, dan kegiatan yang responsden lakukan atau dialaminya. Bentuk kuesioner yang dibuat adalah berupa bentuk pertanyaan, pernyataan.

Kemudian skala pengukuran yang digunakan adalah skala Likert (1-2-3-4), yakni dengan memberikan beberapa item pertanyaan untuk setiap parameter, dengan ketentuan sebagai berikut:

1. Skor 1 merupakan jawaban dari pernyataan dan/atau pertanyaan tidak mau/tidak butuh/tidak mampu/tidak setuju/tidak pernah.

2. Skor 2 merupakan jawaban dari pernyataan dan/atau pertanyaan kurang mau/kurang butuh/kurang mampu/kurang setuju/pernah/ragu-ragu.

3. Skor 3 merupakan jawaban dari pernyataan dan/atau pertanyaan $\mathrm{mau} / \mathrm{butuh} / \mathrm{mampu} / \mathrm{setuju} / \mathrm{kadang}$ $\mathrm{kadang} / \mathrm{jarang}$.

4. Skor 4 merupakan jawaban dari pernyataan dan/atau pertanyaan sangat mau/sangat butuh/sangat mampu/sangat setuju/sering/selalu.

Adapun kisi-kisi dari instrumen penelitian ini adalah sebagai berikut.

1. Variabel Karakteristik Individu $\left(\mathrm{X}_{1}\right)$
Tabel 3. Indikator, Parameter dan Skala Pengukuran Variabel Karakteristik Individu ( $\left.\mathrm{X}_{1}\right)$

\begin{tabular}{|c|c|c|c|}
\hline Variabel & Indikator & Parameter & $\begin{array}{c}\text { Skala } \\
\text { Pengukuran }\end{array}$ \\
\hline \multirow{4}{*}{$\begin{array}{c}\text { Karakteristik } \\
\text { Individu }\end{array}$} & Umur & $\begin{array}{l}\text { Jumlah } \\
\text { tahun dari } \\
\text { lahir hingga } \\
\text { sekarang } \\
\text { dinyatakan } \\
\text { dalam tahun. }\end{array}$ & Ratio \\
\hline & $\begin{array}{l}\text { pendidikan } \\
\text { formal }\end{array}$ & $\begin{array}{l}\text { Pendidikan } \\
\text { formal } \\
\text { terakhir } \\
\text { dinyatakan } \\
\text { dalam tahun }\end{array}$ & Ratio \\
\hline & $\begin{array}{l}\text { Pengalaman } \\
\text { Bertani }\end{array}$ & $\begin{array}{l}\text { Lamanya } \\
\text { waktu } \\
\text { berusaha } \\
\text { tani yang } \\
\text { akan } \\
\text { dinyatakan } \\
\text { dalam tahun. }\end{array}$ & Ratio \\
\hline & $\begin{array}{l}\text { Luas lahan } \\
\text { garapan }\end{array}$ & $\begin{array}{l}\text { Luas lahan } \\
\text { garapan } \\
\text { yang } \\
\text { dimiliki oleh } \\
\text { petani }\end{array}$ & Ratio \\
\hline
\end{tabular}

2. Variabel Faktor Eksternal $\left(\mathrm{X}_{2}\right)$ Tabel 4. Indikator, Parameter dan Skala Pengukuran Variabel Faktor Eksternal $\left(\mathbf{X}_{2}\right)$

\begin{tabular}{|c|l|l|c|}
\hline Variabel & Indikator & Parameter & Skala \\
\hline \multirow{4}{*}{$\begin{array}{c}\text { Faktor } \\
\text { Eksternal }\end{array}$} & Gaya hidup & $\begin{array}{l}\text { Bisnis } \\
\text { Minat } \\
\text { Rekreasi }\end{array}$ & $\begin{array}{c}\text { Modifikasi } \\
\text { Likert } \\
(1-4)\end{array}$ \\
\cline { 2 - 4 } & Peran & $\begin{array}{l}\text { Fasilitator } \\
\text { Inovator } \\
\text { Motivator }\end{array}$ & $\begin{array}{c}\text { Modifikasi } \\
\text { Likert } \\
(1-4)\end{array}$ \\
\cline { 2 - 4 } & Dukungan & $\begin{array}{l}\text { Peraturan } \\
\text { Program } \\
\text { pemerintah }\end{array}$ & $\begin{array}{c}\text { Modifikasi } \\
\text { Likert } \\
(1-4)\end{array}$ \\
\hline
\end{tabular}

3. Variabel Peranan Orangtua $\left(\mathrm{Y}_{1}\right)$

Tabel 5. Indikator, Parameter dan Skala Pengukuran Variabel Peranan Orangtua (Y)

\begin{tabular}{|c|c|l|c|}
\hline Variabel & Indikator & \multicolumn{1}{|c|}{ Parameter } & $\begin{array}{c}\text { Skala } \\
\text { Pengukuran }\end{array}$ \\
\hline \multirow{4}{*}{$\begin{array}{c}\text { Peranan } \\
\text { Orangtua }\end{array}$} & Respek & $\begin{array}{l}\text { Minat } \\
\text { Persepsi } \\
\text { Kesadaran } \\
\text { Kepedulian }\end{array}$ & $\begin{array}{c}\text { Modifikasi Likert } \\
(1-4)\end{array}$ \\
\cline { 2 - 4 } & Sosialisasi & $\begin{array}{l}\text { Partisipasi } \\
\text { Kemitraan } \\
\text { Sikap }\end{array}$ & $\begin{array}{c}\text { Modifikasi Likert } \\
\text { Keterampilan }\end{array}$ \\
& Pewarisan & Modal & Modifikasi Likert \\
\cline { 2 - 4 } & & &
\end{tabular}




\section{\begin{tabular}{|l|l|}
\hline & $\begin{array}{l}\text { Fasilitas } \\
\text { Insfrastuktur }\end{array}$ \\
\hline Pengumpulan Data dan Analisis Data
\end{tabular} \\ Pengumpulan Data}

Data yang diperlukan dalam kegiatan Tugas Akhir ini terdiri atas data primer dan data sekunder. Data primer diperoleh dari hasil pengisian kuesioner yang diberikan kepada responden sesuai dengan tujuan pengkajian. Untuk data sekunder diperoleh dari penelusuran pustaka, maupun lembaga yang berkaitan dengan kajian ini (Kantor Desa, BPP Buay Madang Timur, Dinas Pertanian, Polbangtan Bogor). Teknik pengumpulan data pada kegiatan Tugas Akhir ini adalah dengan menggunakan metode, sebagai berikut:

1. Observasi, yaitu pengumpulan data dengan observasi langsung atau dengan pengamatan langsung terhadap obyek pengkajian yakni suatu kajian sebenarnya.

2. Angket/kuesioner, pengumpulan data dengan menggunkaan instrumen berupa pertanyaan/pernyataan tertulis yang diberikan kepada responden dalam hubungan dengan masalah yang dikaji.

3. Wawancara, yaitu teknik pengumpulan data melalui tanya jawab dengan responden, penyuluh, atau tokoh masyarakat setempat. Wawancara dapat dilakukan secara terstuktur maupun tidak terstuktur dan dapat melalui tatap muka maupun melalui telepon.

4. Studi literatur, yakni dengan cara mempelajari bahan/buku sebagai rujukan untuk memperoleh informasi teoritis yang ada hubungannya dengan masalah yang dikaji.

\section{Analisis Data}

Analisis data yang digunakan dalam penelitian ini adalah sebagai berikut:

\section{Analisis Deskriptif}

Peranan orang tua dalam mendukung regenerasi petani padi (Oryza sativa L.) di Kecamatan Buay Madang Timur dianalisis menggunakan analisis deskriptif. Hasil pengolahan data tersebut sebagai berikut: Untuk pengkelasan peranan orang tua dilakukan dengan menghitung panjang kelas interval dengan menggunakan rumus Kelas interval:

Kelas interval

$=\frac{(\text { Jumlah soal } \times \text { nilai tertinggi })-(\text { Jumlah soal } \times \text { nilai terendah })}{\text { Kategori }}$

\section{Regresi Linier Berganda}

Untuk menganalisis faktor-faktor yang mempengaruhi peranan orang tua dalam mendukung regenerasi petani padi (Oryza sativa L.) di Desa Srikaton, Kecamatan Buay Madang Timur, menggunakan teknik analisis data statistik regresi linier berganda. Karakteristik individu dalam pengkajian ini dibatasi pada umur, pendidikan formal, pengalaman berusaha tani dan luas lahan garapan. Untuk faktor eksternal yang akan dikaji adalah gaya hidup, peran penyuluh dan dukungan pemerintah. Pengkajian ini bertujuan untuk menemukan ada/tidaknya pengaruh antar variabel. Apabila ada, seberapa eratnya pengaruh serta berarti atau tidaknya pengaruh tersebut. Apabila signifikan $<0,05$ artinya terdapat pengaruh, apabila signifikan >0,05 artinya tidak terdapat pengaruh. Adapun persamaan regresi linier berganda (Sugiyono, 2009:258), sebagai berikut:

Rumus persamaan garis regresi linier berganda yang memiliki dua variabel bebas adalah:

$$
Y=\beta_{0}+\beta_{1} X_{1}+\beta_{2} X_{1 \cdot 2}
$$

$$
\begin{gathered}
Y=\beta_{0}+\beta_{1} X_{1.1}+\beta_{1} X_{1.2}+\beta_{1} X_{1.3}+\beta_{1} X_{1.4}+ \\
\beta_{2} X_{2.1}+\beta_{2} X_{2.2}+\beta_{2} X_{2.3}
\end{gathered}
$$

Keterangan :

$\mathrm{Y} \quad=$ Variabel dependen (Peran orangtua)

$\beta_{0} \quad=$ Konstanta

$\mathrm{X}(1,2, \ldots)=$ Variabel bebas

$\beta_{1}, \beta_{2}=$ Koefisien regresi

$\beta_{1} \mathrm{X}_{1.1}=$ Umur

$\beta_{1} X_{1.2}=$ Pendidikan formal

$\beta_{1} X_{1.3}=$ Pengalaman usaha tani

$\beta_{1} X_{1.4}=$ Luas lahan garapan

$\beta_{2} X_{2}=$ Faktor eksternal 
3. Strategi penguatan peranan orang tua dalam mendukung regenerasi petani padi (Oryza sativa L.) di Desa Srikaton, Kecamatan Buay Madang Timur.

Strategi yang dilakukan untuk penguatan peranan orang tua dalam mendukung regenerasi petani padi (Oryza sativa L.) di Kecamatan Buay Madang Timur dideskripsikan berdasarkan hasil pengkajian faktor-faktor yang mempengaruhi. Tujuan dari analisis ini yaitu untuk mengetahui indikator yang terendah. Jika indikator terendah tersebut telah diketahui, selanjutnya indikator tersebut akan ditetapkan sebagai materi penyuluhan yang akan disampaikan.

\section{HASIL DAN PEMBAHASAN}

\section{Deskripsi Petani Sebagai Orang Tua Dalam} Mendukung Regenerasi Petani

Berdasarkan Tabel 6 menunjukkan sebagian besar umur petani berada pada 41 tahun ke atas 94,28\%. Menurut Rukka dan Wahab, (2013) menyatakan bahwa lebih semangat petani berusia muda dibandingkan dengan petani yang berumur lebih tua atau telah berusia lanjut. Didukung dengan umur produktif (15-64 tahun) dan umur tidak produktif ( $<15$ tahun dan $>65$ tahun) (BPS, 2020). Kondisi ini menunjukkan bahwa para orang tua yang berprofesi menjadi petani tanaman padi (Oryza sativa L.) di Kecamatan Buay Madang Timur, Kabupaten OKU Timur berada pada kategori umur menengah dan lanjut sesuai dengan laporan (Liani et al. 2018).

Gambar 2. Histogram dan polygon usia produktif dan tidak produktif 2020 .

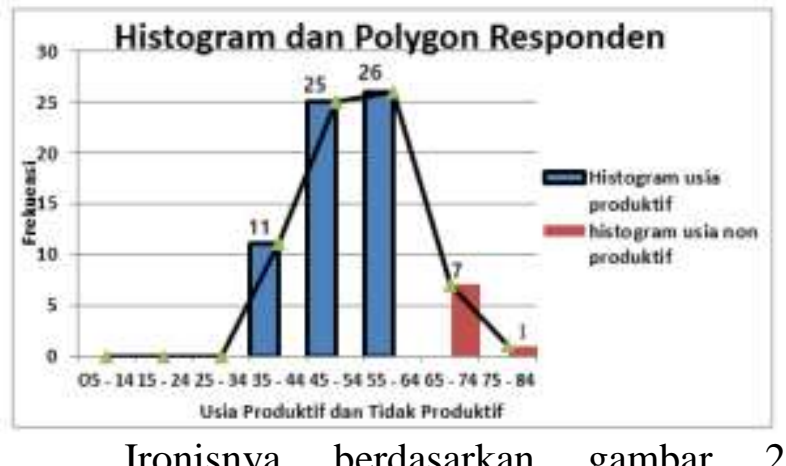

menunjukkan umur responden ada yang telah berumur $\geq 65$ tahun sebanyak 8 responden dan masih berprofesi menjadi petani padi (Oryza sativa L.) yang mana kategori umur ini sudah masuk pada umur tidak produktif (BPS, 2020). Hal tersebut didukung oleh penelitian Sottomayor et al. (2011) yang menyatakan perlunya dilakukan regenerasi petani untuk menemukan pengganti dari para petani yang sudah memasuki masa-masa tidak produktif atau lanjut usia.

\section{Tabel 6. Persentase Karakteristik Individu}

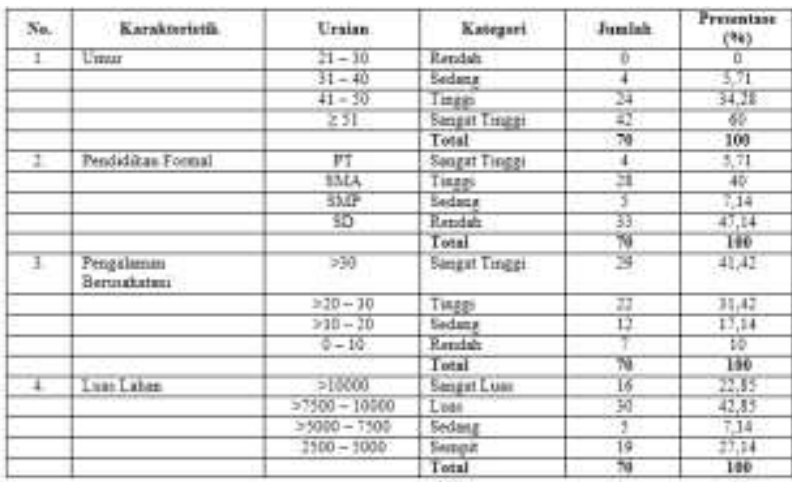

Berdasarkan Tabel 6, pendidikan formal petani sebagian besar dengan porsi $47,14 \%$ adalah Sekolah Dasar (SD) sesuai dengan hasil penelitian (Anwarudin, 2017; Saputra et al. 2018; Liani et al. 2018; Anggini et al. 2019) menyebutkan bahwa pada umunya mayoritas petani berpendidikan formal SD.

Tabel 6 menunjukkan pengalaman berusahatani responden sebagian besar pada kategori sangat tinggi, dengan lama pengalaman $>30$ tahun sebanyak 29 responden dengan porsi $41,42 \%$. Semakin lama pengalaman dalam berusahatani, maka semakin luas pula wawasan, semakin terampil dalam dunia pertanian yang digelutinya selama ini terutama berusahatani padi (Oryza sativa L.). Hal ini didukung dengan penelitian Noer et al. (2018) yang menyatakan bahwa petani yang berpengetahuan luas dan memiliki keterampilan lebih mengenai usahatani diperoleh dari semakin lama pengalamannya dalam berusahatani.

Berdasarkan Tabel 6 luas lahan yang digarap oleh responden mayoritas pada kategori luas, sebanyak 30 responden dari 70 responden dengan porsi $42,85 \%$. Hasil wawancara bersama responden mayoritas lahan tersebut akan diwariskan kepada anak-anak mereka. Hal 
tersebut sesuai dengan penelitian Joose dan Grubbstrom (2017), tentang pewarisan aset nyata berupa lahan pertanian dan aset tidak nyata berupa jaringan pemasaran.

Mayoritas responden memiliki gaya hidup sering mengajak anak-anaknya atau generasi muda dalam kegiatan usahatani mereka dan termasuk dalam kategori sebanyak 50 responden dari 70 responden dengan porsi $71,40 \%$. Sedangkan responden lainnya menyatakan hal yang berbeda sebesar $28,60 \%$ seperti pada Tabel 7.

Tabel 7. Persentase Gaya Hidup Responden

\begin{tabular}{|c|c|c|c|}
\hline No. & Kategori & $\begin{array}{c}\text { Jumlah } \\
\text { Responden }\end{array}$ & $\begin{array}{c}\text { Persentase } \\
(\%)\end{array}$ \\
\hline 1. & $\begin{array}{c}\text { Sangat } \\
\text { Tinggi }\end{array}$ & 9 & 12,90 \\
\hline 2. & Tinggi & 50 & 71,40 \\
\hline 3. & Sedang & 11 & 15,70 \\
\hline 4. & Rendah & 0 & 0 \\
\hline & Total & $\mathbf{7 0}$ & $\mathbf{1 0 0}$ \\
\hline
\end{tabular}

Tabel 8 menunjukkan sebanyak 49 responden dari 70 responden memiliki penilaian yang tinggi terhadap peranan penyuluh dengan angka 70,00\% dalam lingkungan pertanian mereka.

Tabel 8. Persentase Peranan Penyuluh Dalam Lingkungan Pertanian.

\begin{tabular}{|c|c|c|c|}
\hline No. & Karegori & $\begin{array}{c}\text { Jumlah } \\
\text { Responden }\end{array}$ & $\begin{array}{c}\text { Persentase } \\
(\%)\end{array}$ \\
\hline 1. & $\begin{array}{c}\text { Sangat } \\
\text { Tinggi }\end{array}$ & 8 & 11,40 \\
\hline 2. & Tinggi & 49 & 70,00 \\
\hline 3. & Sedang & 13 & 18,60 \\
\hline 4. & Rendah & 0 & 0 \\
\hline & Total & $\mathbf{7 0}$ & $\mathbf{1 0 0}$ \\
\hline
\end{tabular}

Hasil penelitian menemukan mayoritas petani responden memiliki penilaian yang tinggi pada Tabel 9 terhadap dukungan pemerintah dalam mendukung regenerasi petani padi (Oryza sativa L.). Semakin tinggi dari dukungan pemerintah, maka potensi regenerasi petani juga semakin meningkat (Anwarudin et al. 2020).

Tabel 9. Persentase Dukungan Pemerintah.

\begin{tabular}{|c|c|c|c|}
\hline No. & Karegori & $\begin{array}{c}\text { Jumlah } \\
\text { Responden }\end{array}$ & $\begin{array}{c}\text { Persentase } \\
(\%)\end{array}$ \\
\hline 1. & $\begin{array}{c}\text { Sangat } \\
\text { Tinggi }\end{array}$ & 15 & 21,40 \\
\hline 2. & Tinggi & 33 & 47,10 \\
\hline 3. & Sedang & 22 & 31,40 \\
\hline 4. & Rendah & 0 & 0 \\
\hline & Total & $\mathbf{7 0}$ & $\mathbf{1 0 0}$ \\
\hline
\end{tabular}

Berdasarkan hasil analisis statistik yang telah dilakukan. Peranan orang tua dalam mendukung regenerasi petani padi (Oryza sativa L.) di Desa Srikaton, Kecamatan Buay Madang Timur termasuk dalam kategori tinggi dengan nilai persentase peranan orang tua sebesar $85,45 \%$. Indikator tertinggi terhadap pengukuran peranan orang tua dalam mendukung regenerasi petani padi (Oryza sativa L.) berada pada indikator respek dari orang tua dengan nilai persentase $93,12 \%$ pada (tabel 10). Hal ini menandakan bahwa para orang tua telah mengambil langkah awal dengan penanaman atau pemahaman tentang pertanian kepada generasi mereka.

Tabel 10. Persentase Peranan Orang Tua Dalam Mendukung Regenerasi Petani Berdasarkan Indikator

\begin{tabular}{|c|l|c|}
\hline No. & Indikator & $\begin{array}{c}\text { Persentase } \\
(\boldsymbol{\%})\end{array}$ \\
\hline 1 & Respek & 93,12 \\
\hline 2 & Sosialisasi & 80,25 \\
\hline
\end{tabular}




\section{\begin{tabular}{l|l|l}
3 & Pewarisan & 83,57
\end{tabular}}

Faktor-Faktor yang Berpengaruh Terhadap Peranan Orang Tua dalam Mendukung Regenerasi Petani (Oryza sativa L.)

Faktor-faktor yang berpengaruh nyata terhadap peranan orang tua dalam mendukung regenerasi petani padi (Oryza sativa L.) adalah Faktor eksternal (tabel 11). Beberapa faktor yang berpengaruh tetapi tidak nyata terhadap peranan orang tua dalam mendukung regenerasi petani padi (Oryza sativa L.) antara lain umur, pendidikan formal, pengalaman berusahatani, dan luas lahan. Dengan demikian dapat ditemukan persamaan sebagai berikut.

$\mathrm{Y}=2,561+4,136 \mathrm{X}_{2}$

Tabel 11. Pengaruh Peranan Orang Tua, Karakteristik dan Faktor Eksternal Dalam Mendukung Regenerasi Petani Padi (Oryza sativa L.) Di Desa Srikaton, Kecamatan Buay Madang Timur.

\begin{tabular}{|c|c|c|c|c|}
\hline No. & Variabel & Nilai & Signifikansi & Keterangan \\
\hline 1. & $\mathrm{R}^{2}$ & 0,421 & & \\
\hline 2. & Konstantan & 2,561 & 0,013 & Berpengaruh \\
\hline 3. & $\operatorname{Umur}\left(\mathrm{X}_{1.1}\right)$ & $\begin{array}{c}- \\
0,221\end{array}$ & 0,826 & \\
\hline 4. & $\begin{array}{l}\text { Pendidikan } \\
\text { Formal } \\
\left(\mathrm{X}_{1.2}\right)\end{array}$ & $\begin{array}{c}- \\
1,482\end{array}$ & 0,143 & \\
\hline 5. & $\begin{array}{l}\text { Pengalaman } \\
\text { berusahatani } \\
\left(\mathrm{X}_{1.3}\right)\end{array}$ & 0,774 & 0,442 & \\
\hline 6. & $\begin{array}{l}\text { Luas Lahan } \\
\left(\mathrm{X}_{1.4}\right)\end{array}$ & 1,016 & 0,313 & \\
\hline 7. & $\begin{array}{l}\text { Faktor } \\
\text { Eksternal } \\
\left(\mathrm{X}_{2}\right)\end{array}$ & 4,136 & 0,000 & Berpengaruh \\
\hline
\end{tabular}

Penelitian ini menemukan bahwa faktor eksternal berpengauh positif terhadap peranan orang dalam mendukung regenerasi petani. Semakin tinggi gaya hidup yang cenderung kedunia pertanian, peranan penyuluh dan dukungan pemerintah, maka semakin meningkat peranan orang tua dalam mendukung regenrasi petani padi (Oryza sativa L.). Setiap kenaikan 1 poin faktor eksternal meningkat 4,136 poin potensi peranan orang tua dalam mendukung regenerasi petani padi (Oryza sativa L.).

\section{Strategi Penguatan Peranan Orangtua Dalam Mendukung Regenerasi Petani}

Berdasarkan hasil analisis regresi berganda dapat diketahui bahwa yang mempengaruhi peranan orang tua dalam mendukung regenerasi petani adalah faktor eksternal. Oleh karena itu, rumusan strategi penyuluhan yang dapat dikemukakan adalah:

1. Gaya hidup orang tua yang sering mengajak generasi mereka atau generasi muda dalam kegiatan usahatani mereka serta berkunjung ke lokasi wisata pertanian. Sehingga diharapkan muncul minat untuk menjadi petani atau pengusaha pertanian dari dalam diri generasi muda.

2. Strategi penguatan peranan orang tua dalam mendukung regenerasi petani yaitu peran penyuluh. Strateginya dengan mengikutsertakan generasi muda dalam kegiatan penyuluhan pertanian. Sehingga para generasi muda memperoleh ilmu pengetahuan, teknis dan peluang bisnis dalam dunia pertanian.

3. Untuk mendukung regenerasi petani, pemerintah lebih sering memberikan program pelatihan pertanian terhadap petani muda. Seperti magang di balai-balai kementerian pertanian, pelatihan teknis dan kewirausahaan pertanian.

\section{PENUTUP}

\section{Kesimpulan}

Hasil dari penelitian ini dapat disimpulkan bahwa:

1. Peranan orang tua dalam mendukung regenerasi petani padi (Oryza sativa L.) Berada pada kategori tinggi dengan persentase $85,45 \%$.

2. Peranan orang tua dipengaruhi oleh faktor eksternal yang meliputi gaya hidup, peranan penyuluh dan dukungan pemerintah. Dengan demikian untuk meningkatkan peranan orang tua dalam mendukung regenerasi petani padi (Oryza sativa L.) dapat dilakukan dengan 
miningkatkan gaya hidup yang lebih cenderung ke pertanian, peranan penyuluh dan dukungan pemerintah.

3. Strategi penyuluhan yang dilakukan untuk meningkatkan peranan orang tua dalam mendukung regenerasi petani padi (Oryza sativa L.) yaitu (1) gaya hidup orang tua yang sering mengajak generasi mereka atau generasi muda dalam kegiatan usahatani mereka serta berkunjung ke lokasi wisata pertanian. Sehingga diharapkan muncul minat untuk menjadi petani atau pengusaha pertanian dari dalam diri generasi muda. (2) Strategi penguatan peranan orang tua dalam mendukung regenerasi petani. Strateginya dengan mengikutsertakan generasi muda dalam kegiatan penyuluhan pertanian. Sehingga para generasi muda memperoleh ilmu pengetahuan, teknis dan peluang bisnis dalam dunia pertanian. (3) Untuk mendukung regenerasi petani. Pemerintah lebih sering memberikan program pelatihan pertanian terhadap petani muda. Seperti magang di balai-balai kementerian pertanian, pelatihan teknis dan kewirausahaan pertanian.

\section{DAFTAR PUSTAKA}

[1] Anggini D, Hartono R, Anwarudin O. 2019. Perilaku petani dalam pemanfaatan limbah sayuran sebagai pupuk bokashi pada tanaman sawi putih. Jurnal Triton. 10(1): 99-115.

[2] Anwarudin, O. 2017. Faktor Penentu Partisipasi Petani pada Program Upaya Khusus Padi di Kabupaten Manokwari, Papua Barat. Jurnal Penyuluhan Pertanian. 12(1): 67-79.

[3] Anwarudin, O., Sumardjo., Satria, A., Fachiya, A. 2020. Peranan Penyuluh Pertanian Dalam Mendukung Keberlanjutan Agribisnis Petani Muda Di Kabupaten Majalengka. Jurnal Agribisnsi Terpadu. 13(1): 17-36.
[4] Badan Pusat Statistik. 2013. Sensus Pertanian 2013. Jakarta: Badan Pusat Statistik Indonesia.

[5] FAO.1989. Sustainable Development and Natural Resources Management. TwentyFifth Conference, Paper C 89/2 simp 2, Food and Agriculture Organization, Rome.

[6] Joose S, Grubbstrom A. 2017. kontinuitas dalam pertanian - bukan hanya bisnis keluarga. Jurnal Studi Pedesaan. 50 (2017): 198-208.

[7] Liani F, Sulistyowati D, Anwarudin O. 2018. Perspektif Gender dalam Partisipasi Petani pada Kawasan Rumah Pangan Lestari (KRPL) Tanaman Sayuran di Kecamatan Kersamanah Kabupaten Garu Provinsi Jawa Barat. Jurnal Penyuluhan Pertanian. 13(1): 21-32.

[8] Lobley M, Baker J R.2012. Succession and retirement in family farm businesses (Chapter 1). Ini: Lobley, M., Baker, J.R., I. (Eds), Leeping it in the family. International Perspestives on Succrssion and retirement on Family Farm. Ashgate, Altershot. 1-20.

[9] Mardikanto, T. 2009. Sistem Penyuluhan Pertanian. Sebelas Maret University Press. [10] Nazaruddin, \& Anwarudin, O. 2017. Pengaruh Penguatan Kelompok Tani Terhadap Partisipasi Dan Motivasi Pemuda Tani Padi Usaha Pertanian Di Leuwiliang, Bogor. Agribisnis Terpadu, 114.

[11] Noer SD, Zakaria WA, Murniati K. 2018. Analysis of Production Efficiency of Upland Rice Farming in Sidomulyo Subdistrict South Lampung Regency. Jurnal Ilmu Ilmu Agribisnis. 6 (1):19.

[12] Nurmalina, R., Fariyanti, A., \& Kiloes, M. 2018. Pengaruh Faktor Internal dan Eksternal Terhadap Perilaku Kewirausahaan dan Dampaknya Terhadap Kinerja Usaha Petani Anggek.

[13]Ritonga. A., Erlina, dan Supriadi. 2015. Analisis Peran Pemuda Pedesaan Pada kegiatan Pertanian Berkelanjutan Di 
Kabupaten Labuhanbatu Utara. Jurnal Pertanian Tropik. Vol II (3): 311-322.

[14]Rukka, H., Wahab, A. 2013. Faktor-Faktor Yang Mempengaruhi Motivasi Petani Dalam Pelaksanaan Kegiatan P2BN Di Kecamatan Barru, Kabupaten Barru. Gowa: Jurnal Agrisistem. 9 (1): 46-56.

[15] Saputra C. Anwarudin O. Sulistyowati D. 2018. Persepsi dan Adopsi Pengendalian Hama Terpadu Lalat Buah pada Tanaman Mangga di Kecamatan Greged Kabupaten Cirebon Provinsi Jawa Barat. Jurnal Penyuluhan Pertanian. 46- 60.

[16] Sottomayor M, Tranter R,Costa L. 2011. Kemungkinan suksesi dan sikap petani terhadap perilaku masa depan mereka: bukti dari survei di Jerman, Inggris dan Portugal. International Journal of Sociology of Agriculture dan Foot. 18(2): 121-133.

[17] Susilowati, Sri Heri.2016.Fenomena Penuaan Petani dan Berkurangnya Tenaga Kerja Muda serta Implikasinya Bagi Kebijakan Pembangunan Pertanian.Forum Penelitian Agro Ekonomi.Bogor: Pusat Sosial Ekonomi dan Kebijkan Pertanian, Vol 34 No 1.

[18][UU] Undang-Undang Nomor 16. (2006). Tentang Sitem Penyuluhan Pertanian, Perikanan dan Kehutanan. Kementerian Pertanian. 53, 160.

[19]Zagata, Sutherland LA. 2015. Mendekonstruksi masalah kaum muda petani di Eropa: terhadap agenda penelitian. journal of Rural Studies. 38 (2015): 39-51. 
HALAMAN INI SENGAJA DIKOSONGKAN 